\title{
5 Manifestation of Dalit rights, justice and Dalit-ness in the post-Mandal era
}

\author{
Maya Suzuki
}

\section{Diluted Dalit rights and justice}

The long debates about Dalits and Dalit movements have centered on the ideas and ideologies of equality, dignity, justice, and rights, all mutually linked and each a set of irreplaceable values underlying universal fundamental rights. In the context of Dalit movements, the intense argument on rights and justice was sparked after the post-Mandal when reservation policy was gradually extended to lower-caste communities (Other Backward Classes, OBCs) in an administrative term. It led to widespread anti-reservation protests by upper castes. What is worse, it led to nationwide caste-driven violence in the 1990s.

Assertions of Dalit rights have been met with persistent oppression and violence including atrocities. The numbers of crime cases have included honor killings of Dalit youth for marrying a girl/boy from a higher caste, lynching Dalits tasked with disposing of dead cows and leather processing in the name of 'holy cow protectors', and forced labor and humiliating jobs related to death, filth, and human waste. All these cases are violations of existing law. As one instance, the government has banned the practice of manually removing human waste from dry latrines or open sewers by enacting a central legislation known as the 'Employment of Manual Scavengers and Construction of Dry Latrines (Prohibition) Act, 1993'. ${ }^{1}$ However, dry latrines and manual scavengers exist today in many states (Darokar 2018; Ramaswamy 2005; Singh [2012] 2014; Thekaekara 1999). According to Socio Economic and Caste Census 2011 data, 182,505 manual scavengers exist in the rural areas. Despite this, not a single case of violation of the law has been punished and convicted, at least between 2014 and 2016. ${ }^{2}$

A recent Supreme Court judgment (known as the 'Mahajan Judgement') on 20 March 2018 related to the Scheduled Castes (SCs) and Scheduled Tribes (STs) (Prevention of Atrocities) Act of 1989 has drawn stringent criticism from SC/ST activists. The judgment expresses the view that a preliminary inquiry conducted by the appointing authority or senior superintendent of police is required before registration of a first information report (FIR). However, strong distrust of police exists among Dalits. In fact, such cases have quite a low rate of conviction. With regard to the disposal of cases by courts in 2014, only $3.9 \%$ cases of all cases for trial during 2014 (including pending cases from the prior year) for crimes committed against SC led to conviction; $85.3 \%$ were pending. The conviction rate of 
$28.8 \%$ was reported among all cases in which trials were completed during the year (Government of India, Ministry of Home Affairs, National Crime Records, 2015: 109 and Table 7.4). The National Commission for the Scheduled Castes Commission (NCSC) has noted this delay in judicial processes and has expressed concern that instances of procedural lapses are frequent while dealing with atrocity cases by both police and civil administrators (NCSC Annual 2015-16: 285). Given this unfavorable condition of Dalits, is it fair to say the Mahajan judgment by the Supreme Court would enforce prompt and effective registration of FIRs and consequently assure the rights and justice of Dalits and Adivasis?

In contemporary Indian society, the notions of equality, dignity, justice, and rights are not merely symbolic. They are understood as a substantial and realizable entitlement through collective action (Mangubhai 2014). It is noteworthy that a new manifestation of inequality and injustice among Dalits has been observed. For instance, public litigation activities have been observed increasingly among Dalits since the 1990s in the judicial sphere (Suzuki 2017). This article represents an attempt to highlight the awareness of justice, rights, and "Dalit-ness" (Narayan 2005) from interviews with the Balmiki community (known as the sweeper caste and economically and politically vulnerable and socially long-marginalized groups, among the lowest castes in the caste hierarchy). The interview research conducted by the author will shed light on a particular way in which upwardly mobile Dalits, including activists/non-activists, experience their Dalit-ness and how they regard tension between their caste identity and new status.

\section{Situating Dalit movements in the post-Mandal era}

In the post-Mandal era, national and regional Dalit organizations have emerged and emphasized the articulation of an autonomous identity for Dalit and the formation of their leadership potential. They seem to evolve with common aims to overcome caste hierarchy and abolish the practice of untouchability in pursuit of dignity and equality. Nevertheless, the situation is complicated by the existence of various movements embracing different visions and strategies (Gorringe 2005; Pai 2010; Shah 2004). The Dalit are not a homogeneous group: they are differentiated in terms of sub-caste and region.

One feature of contemporary Dalit movements is that their aims have been to empower Dalits to assert their rights. For instance, the Navsarjan Trust, an nongovernmental organization working among Dalits in Gujarat since 1989, trained several hundred youth activists as lawyers. The founder, Martin Macwan, says, "The Dalit response to caste realities has been twofold: economic and educational development on the one hand and the effective use of law to challenge the discrimination (on the other)."3 Similar Dalit organizations attempt to motivate members of the younger generation to learn law. Most highly educated Dalits acknowledge admiration for B.R. Ambedkar's pioneering legal work in drafting the Constitution, with underlying Dalit entitlement of fundamental rights and other protective measures including reservation policies.

During the last decade, a considerable number of state, national, and global networks and organizations have emerged among Balmiki activists in Delhi. 
It is noteworthy that they are organized mostly by educated Balmikis who have attained white-collar jobs through the SC reservation policy. Particularly, lawyers in the community have taken the lead in raising questions related to the ongoing SC quota. They seek to secure an equal share through policy review through judiciary action, known as public interest litigation (PIL) to the Supreme Court (Suzuki 2017). How have the upwardly mobile Balmikis perceived themselves and started to manifest a sense of Dalit-ness? Can we say it is sort of an automatically spontaneous phenomenon that is apparent in common with other educated Dalits? These questions are examined in the next section. I explore the perceptions of upwardly mobile Balmikis including activists and non-activists. The following sections specifically examine the difficulties experienced by Dalits because of their caste and the internal conflict that arises as they struggle to overcome these difficulties.

\section{Manifestation of Dalit-ness}

In what ways do caste-origin difficulties manifest themselves in the lifeworld of Dalits who live in cities? I argue that new signs of changes are evident in the experiences of people who have been "liberated" from discriminated occupations, particularly sweeping jobs in the context of the Balmiki caste.

What is interesting about the manifestation is that people do not necessarily show explicit resistance to the discrimination they must confront although they are placed under similar discriminatory circumstances. People make different "choices" depending on the situation while dealing with conflict in ways such as by developing an aversion to cleaning work and concealing their identity as $\mathrm{SC} /$ Balmiki from others (sometimes including one's own children). This article reveals that these "choices" manifest themselves during major life events, for example, when they move up in life to the next stage such as in education, marriage, and finding a job. This study identifies forms of resistance and repulsion that cannot be captured by visible collective action, from interviews. In doing so, one can describe the conflict Balmikis face and the response they choose to present vis-à-vis the discrimination they encounter.

Dalit literature is important for exploring Dalits' internal world, revealing the stigma they face and their identity. Publication by Dalits has been on the rise since the 2000s. Topics include Dalits' caste awareness, their discrimination-related experiences, and their "success stories" of overcoming adversity, all of which have remained unknown to the public, but which are now being discussed (Khandekar 2013; Moon 2002; Shyamlal 2001; Valmiki 2003). Among the Dalit writers whose works have been translated into languages other than Indian languages, some have attracted global attention. The autobiography of Omprakash Valmiki (2003), Joothan (Leftover), has been translated from Hindi to English. It has gained readership even outside India. ${ }^{4}$

The active publication scene is supported by the Dalit Panther Movement, which began in Bombay (present-day Mumbai) during the 1960s and 1970s to demand social change. Raja Dahle (1940-), a devoted follower of Ambedkar, and Namdeo Dhasal (1949-2014), produced literary works criticizing the caste 
hierarchy. Because the movement was centered in the state of Maharashtra, much of the early writing was in Marathi. Today, their works are published in various languages of India. The majority of writers are Dalit men. ${ }^{5}$ They describe in their work the discrimination they have experienced during the process of attaining their positions and the questions about their identities they had to face in relation to their caste community.

The discrimination and oppression against Dalits, as described in Dalit literature, are unique and peculiar to them. In this regard, Narayan (2005) makes an important point. He argues that awareness and consciousness of the oppressive situation, which can be called "Dalit-ness," is not attributable to nature. He states it as follows:

[W]e must not think that dalit-ness is the natural outcome of the historic injustices meted out to the dalits. The academic study of marginalized or subaltern groups often suffer from this lacuna: one simply assumes that victimhood would lead to protest. . . . I have shown in my earlier works how dalitness is constructed and produced through mobilizations and discourses. There is nothing 'natural' about it.

(Narayan 2005: 126, emphasis in the original)

The perspective of non-spontaneous awareness of being discriminated against and its (re-)constitution is a theme found in research into long-oppressed communities other than Dalits. ${ }^{6}$ In interviews conducted for the present study, when asked, "Have you ever experienced discrimination because of your Balmiki caste?" many respondents would respond, "Yes, I have." Asked how they dealt with discrimination, various responses were received: some would "laugh it off," saying, "I cannot help it if I am Balmiki." " Others described details of how they were unable to attend school when they were children. Some others shared their painful experiences of being harassed and bullied by the teacher and students because of which they started private English lessons for the community at their home. ${ }^{8}$ Some said they started movements against discrimination in recruitment and at the workplace. Not all members of the community share a homogeneous awareness of being a target of discrimination merely because they belong to the same community. Moreover, although they might have experienced similar discrimination, not everyone was willing to join a resistance movement. The author continued to mull over these questions during extensive conversations with several Balmikis in Delhi.

The next section presents details about the ways in which Dalit-ness manifests itself at various major life events (moving onto the next stage in education, finding a job, marriage). It is noteworthy that "role model awareness," which appears sharply in narratives of highly educated Balmikis, is the force driving the movement.

\section{Embarrassment about stigmatized labor}

The relation between caste and occupation is very deep in the case of the Balmikis. Particularly, the scavenging work attributed to them readily reminds one of the 
discriminatory aspects of the caste hierarchy. When talking to Balmikis, the author initially became aware of their eagerness to convey that they, their family, and their relatives had all strived to cut all of their associations with scavenging labor.

From my observations, a hierarchical order exists in the community according to occupation. Particularly "whether they are engaged in scavenging occupation or not" serves as the first major criterion. In fact, this is a salient issue considered when highly educated Balmikis seek to marry. The criterion is applied not only to the prospective spouse but also to the whole family and all relatives. Discrimination against sweeping work is prevalent in the community. Most avoid it because it leads to humiliation. M.K. Gandhi's "ideal Bhangis," the idea that the sweeper caste should be the experts in cleaning, is clearly a concept rejected by the Bhangis themselves.

Those engaged in scavenging jobs are further divided into the "organized sector" and the "unorganized sector" at the place of work. In evaluating the organized sector, indices such as "permanent/casual laborer," "sanitary inspectors/general sweepers," "road sweepers/building cleaners/working at the refuse dump/train/ public latrines," and "positions in the trade union" are regarded as important. Even if one is a casual laborer, working in the governmental sector is regarded as superior. By contrast, scavengers in the unorganized sector are engaged in doing various tasks (cleaning private homes/cleaning sewage/cleaning dry latrines), some of which involves human excrement (manual scavenging, often designated as MS): the most despised type of work.

When the purpose of the research was explained, my request for an interview was sometimes turned down, perhaps because of MS: "Do you want to research those people who are doing that work? We are completely different." Alternatively, a respondent stopped cooperating by saying, "Do you want to know if any of my relatives do cleaning work? Why do you ask about cleaning only? Do not you have any other questions?"

These experiences underscored that talking about scavenging is an extremely unpleasant topic for Balmikis because it associates them with their discriminated caste. Here, we see the awareness of being labeled as the "sweeper caste" and the strong sense of offense it creates.

Kumar, a social activist in his mid-fifties, retired early from a civil servant post (a senior post in the state government). He denies a relation exists between the caste and occupation as follows (the quote is omitted):

You should not confuse the occupation and samaj (caste community) because not all sweepers are Valmikis. ${ }^{10}$ Other castes are also working in sanitary departments. I strongly request that you not conflate Valmikis and scavengers. You can change your occupation as many times as you like, but you can not change your samaj from birth until death. The reason I am Valmiki is simply because my father was Valmiki. Religion is exactly the same. If you see Valmikis as sweepers, you can not understand things correctly. ${ }^{11}$

In his words, one can sense the offense he feels and his rejection of being labeled as one of the "sweeper caste." At the same time, it is interesting to observe how 
he talks about the Balmiki caste in a positive manner, having severed the linkage to cleaning work. Kumar argues that "for our samaji, to develop further, we have to be proud of being descendants of the legendary saint Valmiki. Then we have to acquire jobs that command people's respect by working hard." His story is a typical one among the elite Dalits who have "achieved wealth and social status through self-help and hard work." He argues that negative images embedded in the caste must be wiped out.

Initially, Kumar was rather suspicious of me and wanted to know complete details of the people I had interviewed to date and the Balmiki events in which I had participated. He talked about his work and current situation fluently in English, but when I asked about his personal history and home village, he became suddenly quiet, merely saying, "My story? Just a line. I was born in a poor and downtrodden family," which left a deep impression on me (I have not managed to confirm his year of birth, family composition, or name of the village and school).

Based on the limited information I received, I was able to infer that Kumar was born in a rural area in the western part of Uttar Pradesh near Delhi. His parents, who were landless peasants, worked in the field for a landlord and cleaned houses in the area to make ends meet. When he was young, Kumar helped his parents in their work. He talked about his parents:

My father and mom were uneducated. Both of them were uninterested in their children's education. Only I among our siblings had become educated and had attended graduate school. My father never knew about how prestigious a school I had studied in. One day, an upper caste sadhu (Hindu ascetic) asked my father, "what is your son's qualification?" Then he answered with arms spread, "bahut parha! (studied a lot)!" (Laughing) You know, my father didn't know about my education that much. ${ }^{12}$

Kumar's narrative describes his family leading a life in which education had little role or meaning. At the same time, it conveys his "toughness" in surviving by making light of the past about his father, who was uninterested in his son's education and even "ridiculed the possibility."

When asked about life in the village, while saying "there is nothing special to talk about," he described his life.

KUMAR: Our only happy time was when we received leftovers from big marriage parties and ceremonies in our native village. If we took the leftovers, upper caste people were also happy. We respect them . . can you understand our feeling? In the village I used to wash cars owned by others. But what happens now? I hire people to come to clean my car and house. Isn't it miracle?

AUTHOR: Have you told your son about your past life?

KUMAR: No! Never! If I tell him, it might negatively affect him. ${ }^{13}$

The practice in which Dalits are given leftover food from higher castes is often described as a symbol of discrimination against the untouchables (Valmiki 2003). Kumar's narrative suggests that Dalits live in such poverty-stricken conditions that 
they must rely on leftover food. Then they are aware of the fact that by receiving leftover food, the discriminating-discriminated relationship between the higher castes and Dalits is reinforced. B.R. Ambedkar is said to have called for boycotting the practice of receiving leftover food as part of the liberation movement, but it was a form of resistance that could put one's life at risk because it could invite violent reprisal.

Kumar organizes regular meetings to celebrate the tradition of Saint Valmiki. In 2008, he organized a three-day International Valmiki Workshop in Delhi. In addition to Balmiki politicians, researchers, and activists from across India, several Balmikis who had migrated abroad were invited. He says he is concentrating on building a global network. While saying "there is nothing special to talk about," his reluctance to talk about his past reflects his wish that his son not know about it. This reluctance is the driving force behind Kumar's activities. One glimpses his internal conflict related to his inability to escape from a discriminatory "sweeper caste" category despite severing his links to a cleaning past.

Next, we examine the case of Vijay, who, while emphasizing his escape from cleaning work like Kumar described earlier and keeping his distance from scavenging as a lawyer, tries to maintain his link to the caste of his community by engaging with a movement to improve the life of sweepers. Vijay (in his early seventies) was born in Ludhiana, a city in the state of Punjab. After graduating from the governmental college, he moved to Delhi on finding employment. Having retired from his civil servant position (middle-ranking clerical position in the central administration), he works as a barrister at the Delhi High Court and is engaged in social activities. Similar to Kumar's statements, Vijay emphasizes severance of the link to cleaning work:

My father worked as a sweeper in Indian Railways. My mother also worked as a sweeper in the British cantonment area in my childhood. When I started to go to school, she quit her job because my father did not allow her to continue. I have seven sisters. No one does the job. It is the same with my wife and two sons. I will never let them do it! ${ }^{14}$

Vijay used to live in a sweeper colony for New Delhi municipal government employees. At the time of my fieldwork, he owned two apartments in public housing in South Delhi, which he had purchased before his retirement. When he first moved to Delhi in 1962, he was unable to find a place in the government accommodations and lived for a while in a flat that belonged to his wife's relative who lived in a sweeper colony. In contrast to Kumar, who is mostly engaged in religious activities of the community and who keeps his distance from scavenging labor, Vijay lives in an area where sweepers are concentrated. He is aware of the pressing problems in their working environment, such as irregular employment and bribery. Consequently, his position is that we should prioritize practical improvement in life support, such as by establishing a car repair workshop as a vocational school for youngsters, helping them resolve legal matters, and voicing demands to revise the SC reservation policy. Therefore, he is involved in a movement to recover ownership of a colony of residents. He helps with document production and in negotiating with the authorities. 
What left a deep impression on me after fieldwork in sweeper colonies was the attitude of the Balmiki residents in trying to "find a compromise." Frankly, they want to leave their scavenging work, which engenders discrimination. If they have a permanent job, they can live in governmental accommodations in the city center, send their children to school, and support the family. To my question, "Are you satisfied with the work you do now?" many briefly replied, " $[K]$ arnā hae" (Cannot be helped), and continued working as a sweeper for two or three generations. ${ }^{15}$

Sanjay, a college student in his early twenties, has been brought up by his grandfather and father, both government sweepers, and by his mother, who commutes to a nearby residential area for her cleaning job. When I asked, "When you graduate, what kind of job do you want to have?" he immediately answered, "[S]arkari naukri" (Government job). When asked a difficult question, "If you get only a cleaning job like your father, what will you do? He answered, "I cannot answer immediately ... but if it is the only available job, it cannot be helped." This was followed by, "In the past, in my grandfather and father's time, it was easy to obtain a sweeper job, but now there is so much competition. It is not easy because we have to pay a bribe." ${ }^{16}$ Sanjay's narrative suggests that although he has studied up to college level, his opportunities for finding employment are restricted. It was also confirmed that he has not experienced discrimination because of his caste at the college because many of his friends are from the same sweeper colony. The next section presents an examination of narratives about schools and education as a place where Dalits are first made aware of their caste.

\section{Schooling experience: learning about one's caste ancestry and reservation policies}

Persons belonging to the lower castes, such as Balmikis, often find it "awkward and troublesome" to reveal their caste. Fieldwork has also revealed that people do not refer to their caste by name but instead refer to it as "yeh samāj" (this community). This tendency is apparent even during indoor conversations with people. During the course of a conversation between the previously described Vijay and me, when our conversation became excited, his wife would come in from the next room to say, "Hey, please be quiet. People can hear you from outside."

Another interesting incident occurred. One day, when I was having lunch at Vijay's home, a neighbor dropped in. On seeing me, a stranger and a Japanese person, he asked me, "What relationship do you have with Vijay ji?" As I was about to introduce myself, Vijay's wife interrupted and replied quickly, "She has come to help my husband with his computer." Later, it turned out that Vijay's caste was not known to the neighbors (more precisely, although it is known that he is from the SC, his exact caste is not known). She was worried: "As soon as they learn we are Balmikis, their respect for us will immediately disappear. They will try to hide it, but I will know."

This concern is shared by many informants, not just Vijay's wife, who has told me about similar experiences. The worry about one's caste is most likely experienced for the first time when one leaves one's familiar sweeper colony to start 
schooling with others. How they deal with the situation that arises there and how they overcome it to establish their identity differs among individuals.

Rajesh (in his early forties) is a former member of the Legislative Assembly of Delhi. He was active in politics while studying at the University of Delhi. He served as the representative of the Delhi Pradesh Youth Congress, consisting mainly of young Congress activists. He was first elected as a member of the Legislative Assembly of Delhi (in the constituency reserved for SCs) at the age of thirty-four. He served two terms (2003 and 2008 elections), but he was defeated in the 2015 election by a candidate of the Aam Aadmi Party who gained popular support on the promise of eliminating corruption.

Rajesh's family is in the trade business. He was brought up in a financially comfortable environment. His parents did not attend school but understood the importance of education. All their five sons and two daughters received an education. Of them, only Rajesh became a politician. Rajesh's family members were all of strong build; his father practiced wrestling. His grandfather served as a bodyguard to Mahatma Gandhi. At an early age itself, Rajesh was noted for being good at academic work and sports. He was elected as a class representative. The first turning point in his life occurred when he was an adolescent:

It happened in the tenth grade. Until then, I had no idea about my caste, Balmiki. My parents didn't tell me. I used to go to private English medium school where no one cared about caste. One day in the tenth grade, a teacher gave a small piece of paper only to SC students. I didn't know what to do, and wrote "NA" on the paper and submitted it. After that, the principal called my father and told [him,] "Your son doesn't know he is SC." On that day, my father explained to me about my caste, Balmiki. I was so upset and cried all night. I clearly remembered how I felt in my classroom the next day. I could not stop feeling all the stares from a girl sitting next to me. Now I can understand she was just looking at me as usual, but at that time, I couldn't help thinking that she was watching me because I was from SC. ${ }^{17}$

He was shocked. His view of life changed completely. He was deeply hurt when he was informed of his caste, but his father encouraged him, saying, "Although your caste cannot be changed, you can still go on to become a great person. To put the others to shame, make efforts to be the best in studies and everything else." It is not rare for Balmikis from financially comfortable families to be brought up without being ever told by their parents about their caste. However, when carrying out the formalities for admission to a school or applying for scholarships, various certificates are required. They come to know that they are Balmikis, SC.

At college, Rajesh was absorbed in politics. When he was elected as the president of the Delhi Pradesh Youth Congress, he decided to become a politician supporting the Congress Party. He says that later he had to face a situation in which a recommendation for his promotion was withdrawn because he was a Balmiki, but each time he motivated himself by recalling his father's words. 
Arun (in his late forties), the chief doctor of the medical department of a governmental institution, says he is proud not only of his current occupation but also his leading role in resident welfare association:

The condominium where I live had 260 flats. I was first in the president election. Everyone respects me so much that I am very happy. ${ }^{18}$

Arun's father moved to Delhi from a rural village in the state of Uttar Pradesh. His grandfather was a supporter of education. Therefore, Arun's father and his two older brothers received education up to the tenth grade. Arun's father wanted to continue his studies, but because the family did not have the financial resources to fund further education, he found a clerical post in the central government in Delhi. Supported by his father, who was a firm believer in the importance of education and the opportunities it would bring, Arun and his two younger brothers were educated. Each found a job of their choice: One is an engineer with a private airline. The other is a sanitary inspector of New Delhi Municipal Council. Arun's first son is studying at the famed Indian Institute of Technology, Delhi, to become a computer engineer. His wife is a devout Hindu (a devotee of the peer Sai Baba) and a Balmiki. Arun does not make any effort to conceal his caste. In fact, when using the SC reservation to study, get a scholarship, or find a job, one must prove one's caste by submitting the relevant certificates. Nevertheless, he also does not actively publicize it. He rarely participates in any Balmiki meeting or function. Arun emphasizes that for Balmikis to be respected in Indian society, it is essential that they be educated. Then they must improve their standing through their own efforts.

The narrative that "education is the only way to improve the community" is shared by all people from the educated Balmiki background, such as Arun, who have achieved upward social mobility. They pay the utmost tribute to Ambedkar, who played a leading role in incorporating affirmative action policies in the Constitution. Arun explains his own success:

I am deeply obliged to Babasaheb (Ambedkar) for what I am now. I couldn't go to medical school without the SC reservation. I was a top student, but not a first ranker. General students (without reservation) were so brilliant that I always felt inferior to them. But I had good senior friends who were SC; they helped my study and reading lists with "mantra" (secret methods) to have confidence. I faced discrimination at school. It happens everywhere, so I have learned to be prepared for any difficult situation. I tried doing my best to be equal to general students or above them. ${ }^{19}$

In his own narrative, Arun's success is attributed to (a) the reservation policy, (b) Ambedkar who devised it, and (c) his own efforts.

Ram, a former Indian Administrative Service (IAS) ${ }^{20}$ officer in his mid-seventies, is well known in the community as the first Balmiki IAS officer. Ram's elder brother is also a former IAS officer. He is a cautious man who declined my request for an interview three times before finally accepting it. Ram originally 
hailed from the Pakistani part of the state of Punjab before the partition. His father moved to Delhi after the partition. The family was not wealthy, but almost all the five brothers and five sisters became senior or general civil servants with the IAS and other agencies. Ram married a woman from a higher caste. He has two children. His son is working for an information technology company in Bangalore, having graduated from the renowned Indian Institute of Technology. His daughter is preparing to study in the US after graduating from the National Institute of Fashion Technology. When describing his children's achievement in education, Ram emphasized that they chose not to use the SC quota. Ram talked about SC in general but did not provide much detail about the Balmiki in particular. Referring to how the standing of the SC can be improved, like Arun, he emphasizes the importance of education:

Getting education is the only way for SC to improve themselves. If you get high education, other things should follow naturally. In my office, I never experienced discrimination. Once you become an IAS officer, the promotion simply depends on individual performance. Because I held a high post, nobody openly mentioned my caste background, but it was obvious to assume that they had in mind my lower caste status. ${ }^{21}$

There is an SC quota in recruiting for the IAS. However, competition within the $\mathrm{SC}$ quota is fierce. It is extremely difficult to pass this exam when compared to other civil service exams. As in the case of Arun, even when one becomes an IAS officer after successfully completing the competitive exams, caste awareness will linger. When I asked Ram, "When will caste awareness disappear?" his answer was "[I]t will take another four to five generations."

One oft-used phrase by Balmikis when discussing caste awareness and awareness of being discriminated against is "deeply rooted." The awareness is deep and embedded as a stigma for multiple generations irrespective of their upward status or profession. While accepting such awareness, can Balmikis simply be viewed as those who are trying to invest in hope for a future in the long term by acquiring academic achievement and serving in respectable occupations?

\section{Solidarity or exclusion? Rising awareness of the "role model" and "moral imperative"}

Earlier studies have identified the following two points as features of Dalits who have achieved upward social mobility. One is "assimilation" with the new group while concealing their caste and making efforts to move away from the past of discrimination. These people are designated as the "harijan elite" (Mendelsohn 1986; Mendelsohn \& Vicziany 1998; Sacchidananda 1976). The term harijan elite is often used critically. For instance, they are often accused of a strong tendency to monopolize political/social/economic privileges acquired for their community through affirmative action. Criticism of this kind forms the position of those opposing affirmative action including the SC reservation policy. Current policies designed to uplift the Dalits benefit only some Dalits and do 
not engender improvement of Dalits overall. However, the census shows gaps between the SCs and other social groups. Reservation policies can be regarded as effective in "securing representativeness." Therefore, the policies must continue for the time being.

A second feature that contrasts with the "harijan elite" is the active commitment to the cause of education among caste members and social and political activities by those who have achieved upward mobility and who continue to maintain relations with their caste members. In this regard, Naudet (2008), who conducted interviews of SCs with white-collar jobs in the public and private sectors, makes an interesting point. His work describes the strong influence of "moral imperative" on the inner worlds of those who strengthen their relationship with their caste ancestry after achieving upward social mobility. ${ }^{22}$ Furthermore, it has been pointed out that this awareness is conditioned by a situation that is unique to the Dalits: even if they have managed to emerge from material poverty, it has not brought about any fundamental change in their status. In other words, in Indian society, caste never disappears: no one can ever escape from the caste either by trying to conceal their caste to the very end or by positively transforming it with a sense of "pride" by making it public.

A similar expression of "moral imperative" is advocated by Kanshi Ram, who founded the All India Backward and Minority Communities Employees Federation (BAMCEF). The phrase "to pay back to society" is commonly used by activists and participants in Balmiki caste groups and by the BAMCEF. It is the key phrase in arguing for the activities of caste organizations. However, it is assumed that the "society" described here does not refer to Indian society as a whole but to the "samaj" of their affiliated caste.

Additionally, we should devote attention to the term role model. Among the Balmikis who have achieved upward social mobility by studying at the university and by joining professions such as law and medicine, which would have been impossible to even dream about in the past, many are engaged in community activities self-identifying themselves as "role models" for community youngsters. They argue with confidence and pride that only the practice of a "proper" lifestyle will bring about a positive influence on the community. This role model narrative is accepted widely irrespective of whether people are involved or not with the collective actions of the caste group. For instance, Ramesh (in his early sixties), who had just retired from his post of the assistant commissioner of Police, Delhi, described his life in his interview:

I was born in a village of Bulandshahr district, Uttar Pradesh. I went to a village school until fifth grade. The village life was so hard that I have only bad memories. Our community had to serve upper caste landlords as slaves. I could not wear good clothes because my family was poor. I was always worried about how I was looked upon by my classmates. After a while, when my father got a central government job in Delhi, I requested that he take me to Delhi. With admission to sixth grade, I could continue my education in Delhi. I did not experience discrimination there and was able to concentrate on my study. It was my great honor to get admission to a famous school: 
Shri Ram College of Delhi University. After graduation, since I passed a Delhi police examination, I kept doing my best to pass promotion exams and obtain my present post: the Assistant Commissioner of Police. Now I am thinking that the hard time in my village made me strong and competent for future success. ${ }^{23}$

Ramesh says he is not involved in political/social activities of his caste community. From his narrative, it is clear that while his relatives continue to live in his home village, he seldom goes there; he deliberately maintains some distance from his community. When the interview touches on his children's wedding, he says, "I did not invite people from my village. If I had invited them, they would have come and behaved badly by getting drunk and becoming unruly at the wedding venue, which would make a poor impression on my neighbors in Delhi." He continues to criticize the community's lifestyle:

I am polite, do not drink and smoke. Moreover, I am a pure vegetarian. For these reasons, I receive respect from everyone in society. But most poor Balmikis are not (respected). I think there are three reasons why Balmikis have been left far behind in development. Firstly, they are uneducated. Most of them don't send their children to school. Secondly, it's a harmful habit. They habitually drink and eat meat, often pork, which prevents their mental development. Thirdly, it's a bad custom. For instance, while they spend more, they borrow for marriage and other ritual occasions; they can't afford to invest in their children's education. Education is most important for development. If they get good education, they will definitely have a good job and mind like I have. ${ }^{24}$

The awareness of being a role model is commonly apparent among those who have achieved upward social mobility. Members of caste groups become aware of this because of the repeated talk of a "role model," "moral imperative," and "pay back to society." This is regarded as a motivating factor for them to commit actively to such activities.

At the same time, aside from having to commit to such activities for strengthening the members' motivation and their sense of unity, they realize that the scope of their activities is restricted to members of their caste of origin. This fact implies that they tend to suppress their sense of solidarity with people from other Dalit castes. This motivation is regarded as positive within the same caste, but it excludes other castes. Moreover, it can engender fragmentation of Dalit communities and overall movements. The problem with this exclusive element is apparently justified by the so-called moral imperative. Given this situation, we must examine whether awareness of this type can have universality.

\section{Acknowledgments}

This work was supported by JSPS KAKENHI Grant Numbers 14J09056, $16 \mathrm{~K} 16659$. 


\section{Notes}

1 This act was revised as a new act to "The Prohibition of Employment as Manual Scavengers and their Rehabilitation Act, 2013" by reviewing the inadequate performance of the previous act.

2 Government of India. 2015. National Commission for the Scheduled Castes (NCSC), 8th Annual Report 2014-15 (New Delhi: Government of India).

Government of India. 2016. National Commission for the Scheduled Castes (NCSC), 9th Annual Report 2015-16 (New Delhi: Government of India).

3 Lyla Bavadam, "Of Dalit Awakening, Upper-Caste Jealousy," Front Line, June 17, 2018, https://www.frontline.in/social-issues/of-dalit-awakening-uppercaste-jealousy/ article10108744.ece, accessed on July 15, 2018.

4 Some Western universities have designated Dalit writing as prescribed text for their classes (Valmiki, interviewed on August 30, 2011, Dehradun).

5 Dalit women's writings about autobiography and Dalit feminism have been on the rise since 1990s (Pawar 2009; Rege 1998).

6 With regard to the awareness of discriminated minorities, generating their self-esteem is also important. At the seminar with Prof. Tsutomu Tomotsune, a historian of modern and contemporary buraku community, he pointed out that "one cannot declare the low-status origin without self-esteem," and I share the same understanding based on my research; Tomotsune, "The Politics of 'Liberation': The Dynamics of the Dalit Movement" (presentation at the Second Seminar for Young Researchers, Contemporary India Area Studies Center, Tokyo University of Foreign Studies, June 30, 2013).

7 I have seen Balmikis "laughing off" their caste several times. When spending time with the family of an informant, all the family members burst into laughter, saying, "I am a Bhangi?" when they spotted the title of the book Mein Bhangi hun (I am a Bhangi) in Hindi I happened to carry around. Children made fun of the author of the book by asking, "Maya madam (the author), please say 'I am a Bhangi' in Hindi!' and laughed. What this episode taught me was that Balmikis regularly downplayed the attention to their caste. We can see some efforts to transform a negative label.

8 In reference to the statement "I could not attend school due to discrimination," Uehara (2014: 109-110) has identified four meanings in the context of buraku discrimination: (1) It was difficult to feel welcome in the classroom, (2) could not attend school because of discrimination by the teacher and other students, (3) could not attend school because of poverty, arising from discrimination, and (4) could not go to school because parents believed that education is unnecessary and causes despondency due to discrimination. These seem to be equally applicable to the situation in which Dalits find themselves.

9 Balmiki, Bhangi, and Chohra are sub-castes of the sweeper caste and registered in the SC list of Delhi. The chapter's purpose is to focus on a problem that exists in society. The caste names of Bhangi and Chohra are not used herein to derogate the feelings of any person or community.

10 In this chapter, the terms Balmiki and Valmiki are used almost interchangeably as community names. The names are derived from worshipping the Sanskrit "Bhagwan Valmik," known as a legendary saint and composer of the Ramayana. Kumar is a devoted follower of Valmik saint and prefers to identify himself as Valmiki.

11 Kumar, interviewed on December 26, 2013.

12 Kumar, interviewed on January 4, 2014.

13 Kumar, interviewed on January 4, 2014.

14 Vijay, interviewed on July 6, 2008.

15 A major consideration in choosing scavenging work is the benefit in the form of governmental accommodation. This is shared even by highly educated (college-level) Balmikis, who have trouble finding jobs in sectors other than scavenging. Menaka Rao, "Trapped in the Gutter: The Street Cleaner with Four Degrees," BBC News, August 18, 2015, http:// www.bbc.com/news/world-asia-india-33859315, accessed on August 25, 2015.

Narratives the author collected from sweeper colony residents in Delhi confirmed that security is another reason that they continue to live in the area: "it is shanti (peace 
and quiet) here and everyone helps one another"; "atrocities happen in the village and many places in Delhi everyday but here it is very safe." Because they share a degree of family composition, have experience of cleaning work, and largely have the same educational and economic standards, a sense of unity apparently emerges in the community.

16 Sanjay, interviewed on March 30, 2008.

17 Rajesh, interviewed on February 24, 2010.

18 Arun, interviewed on March 18, 2010.

19 Arun, interviewed on March 18, 2010.

20 The Indian Administrative Service (IAS) is a profession that constitutes the All India Services (AIS), which plays a central role in the Indian bureaucracy. It is a highly selective group: about sixty to eighty persons are selected from more than five hundred thousand candidates annually. The All India Services include, in addition to the IAS, the Indian Police Service and the Indian Forest Service.

21 Ram, interviewed on March 17, 2010.

22 It has been pointed out that a difference exists in the behavior of workers from the SCs in public and private sectors. In contrast to the public sector in which the reservation policy is introduced and information about those from the lower-caste background is made public, in the private sector, where the reservation is not fully implemented, there are many cases in which the caste is concealed (Naudet 2008).

23 Ramesh, interviewed on February 22, 2010.

24 Ramesh, interviewed on February 22, 2010.

\section{References}

Darokar, Shaileshkumar. 2018. "Manual Scavengers: A Blind Spot in Urban Development Discourse." Economic and Political Weekly 53(22). https://www.epw.in/engage/article/ manual-scavengers-blind-spot-urban-development-discourse. Accessed on July 14, 2018.

Gorringe, Hugo. 2005. Untouchable Citizens: Dalit Movement and Democratization in Tamil Nadu. New Delhi: Sage Publications.

Government of India. 2015. National Commission for the Scheduled Castes (NCSC), 8th Annual Report 2014-15. New Delhi: Government of India.

Government of India. 2016. National Commission for the Scheduled Castes (NCSC), 9th Annual Report 2015-16. New Delhi: Government of India.

Government of India, Ministry of Home Affairs, National Crime Records Bureau. 2015. Crime in India 2014. New Delhi: Government of India.

Khandekar, Milind. 2013. Dalit Millionaires: 15 Inspiring Stories. New Delhi: Penguin Books India.

Mangubhai, Jayshree P. 2014. Human Rights as Practice: Dalit Women Securing Livelihood Entitlements in South Asia. New Delhi: Oxford University Press.

Mendelsohn, Oliver. 1986. "A 'Harijan Elite'?: The Lives of Some Untouchable Politicians." Economic and Political Weekly 21(12): 501-509.

Mendelsohn, Oliver and Marika Vicziany. 1998. The Untouchables: Subordination, Poverty, and the State in Modern India. New York: Cambridge University Press.

Moon, Vasant. 2002. Growing Up Untouchable in India: A Dalit Autobiography. New Delhi: Vistaar Publications.

Narayan, Badri. 2005. "DomiNation: How the Fragments Imagine the Nation: Perspectives from Some North Indian Villages." Dialectical Anthropology 29: 123-140.

Naudet, Jules. 2008. “"Paying Back to Society”: Upward Social Mobility among Dalits.' Contribution to Indian Sociology (New series) 42(3): 413-441.

Pai, Sudha. 2010. Developmental State and the Dalit Question in Madhya Pradesh: Congress response. New Delhi: Routledge. 


\section{Maya Suzuki}

Pawar, Urmila. 2009. The Weave of My Life: A Dalit Woman's Memoirs. New York: Columbia University Press.

Ramaswamy, Gita. 2005. India Stinking: Manual Scavengers in Andhra Pradesh and their Work. Chennai: Navayana.

Rege, Sharmila. 1998. "Dalit Women Talk Differently: A Critique of 'Difference' and Towards a Dalit Feminist Standpoint Position.” Economic and Political Weekly 33(44): WS39-WS46.

Sacchidananda. 1976. The Harijan Elite: A Study of their Status, Networks, Mobility, and role in Social Transformation. Faridabad: Thomson Press.

Shah, Ghanshyam. 2004. Social Movements in India: A Review of Literature. New Delhi: Sage Publication.

Shyamlal. 2001. Untold Story of a Bhangi Vice-Chancellor. Jaipur: University Book House.

Singh, Bhasha. [2012] 2014. Unseen: The Truth about India's Manual Scavengers. Translated by Reenu Talwar. New Delhi: Penguin Books.

Suzuki, Maya. 2017. "Exclusivity rather than Inclusion: Dalit Assertion in Contemporary Urban India." Senri Ethnological Studies 96: 109-124.

Thekaekara, Mari Marcel. 1999. Endless Filth: The Saga of the Bhangis. Bangalore: Books for Change.

Uehara, Yoshihiro. 2014. Roji no kyousitu: burakusabetsu wo kangaeru (Classroom on the Street: Considering Buraku Discrimination). Tokyo: Chikuma Syobou. (in Japanese)

Valmiki, Omprakash. 2003. Joothan: A Dalit'Life. Translated by Arun Prabha. Maukherjee. New York: Columbia University Press. 